\title{
Effect Of Compaction On Oil Recovery Under Low Salinity Flooding In Homogeneous And Heterogeneous Chalk
}

Hao, Jiasheng; Shapiro, Alexander

Publication date:

2019

Document Version

Publisher's PDF, also known as Version of record

Link back to DTU Orbit

Citation (APA):

Hao, J., \& Shapiro, A. (2019). Effect Of Compaction On Oil Recovery Under Low Salinity Flooding In Homogeneous And Heterogeneous Chalk. Abstract from Danish Hydrocarbon Research and Technology Centre Technology Conference 2019, Kolding, Denmark.

\section{General rights}

Copyright and moral rights for the publications made accessible in the public portal are retained by the authors and/or other copyright owners and it is a condition of accessing publications that users recognise and abide by the legal requirements associated with these rights.

- Users may download and print one copy of any publication from the public portal for the purpose of private study or research.

- You may not further distribute the material or use it for any profit-making activity or commercial gain

- You may freely distribute the URL identifying the publication in the public portal

If you believe that this document breaches copyright please contact us providing details, and we will remove access to the work immediately and investigate your claim. 


\section{Danish Hydrocarbon Research and Technology Centre Technology Conference 2019}

\section{Effect Of Compaction On Oil Recovery Under Low Salinity Flooding In Homogeneous And Heterogeneous Chalk}

Jiasheng Hao ${ }^{a, b}$, Alexander Shapiro ${ }^{b}$

a Danish Hydrocarbon Research and Technology Centre (Centre for Oil and Gas - DTU), Elektrovej 375, DK-2800, Lyngby, Denmark.

${ }^{b}$ Center for Energy Resources Engineering (CERE), Department of Chemical and Biochemical Engineering, Technical University of Denmark, Denmark.

\section{Jiasheng Hao}

\section{AWF.1.A.00 Recovery Processes on Core Scale}

Compaction of the reservoir chalk (e.g. surface subsidence) may facilitate oil production. However, only few works have linked smart water flooding with chalk compaction and additional oil recovery. In this work, core flooding experiments with sequential injection of low salinity brines were performed to examine the effect of chalk compaction on oil recovery under smart water flooding. Xray computer tomography scanning was applied to select outcrop and reservoir cores with different level of heterogeneity, which was demonstrated to be an important factor that determines the recovery even on core scale. A linear variable differential transformer (LVDT) device made it possible to detect changes of the core length during the experiments, which served as an indication of the compaction. Overburden pressure was increased stepwise at the final stages of the flooding to achieve higher compaction of the cores.

During secondary flooding, slight gradual compaction of the cores was observed. Subsequent low salinity flooding did not lead to further compaction for all the samples, nor additional oil recovery. Under final compaction, significantly more oil was produced from the heterogeneous cores, especially, from the reservoir core. Some fines production was observed during the core cleaning after the experiments. Fluid diversion due to closing micro-fractures under compaction and/or relocation of the fines is speculated to be a driving mechanism behind additional recovery from heterogeneous cores. Rock compaction appears to be a potential mechanism for enhanced oil recovery, however with a limited efficiency. 